\title{
Chemical composition of the essential oil extracted from the aerial parts of Zosima absinthifolia Link.
}

Narmin S. Alikhanova ${ }^{1}$

Eldar N. Novruzov

Sevil A. Zeynalova

Institute of Botany, Azerbaijan National Academy of Sciences, Badamdar highway 40, Baku, AZ1004, Azerbaijan

Abstract: The article presents the component composition of the essential oil Zosima absinthifolia Link. (Apiaceae) collected in the vicinity of Shahbuz region of the Nakhchivan Autonomous Republic. The genus is represented by single species in Azerbaijan. Plant raw materials for research were collected during the flowering stage. The essential oil was extracted from the air-dried and finely chopped leaves and stems of the plant by the method of hydro-distillation. The yield of essential oil was $0.7 \pm 0.15 \%$. The component content of the obtained essential oil was determined by the Gas Chromato/Mass Spectroscopy method. In total, 50 substances making up $97.88 \%$ of the essential oil were identified. The major components of the essential oil were octyl acetate (44.76\%), cyclopropane, pentyl-(13.88\%), butanoic acid, octyl ester $(9.47 \%)$. The content of other components is less than $5.5 \%$. Z. absinthifolia essential oil also contains terpene substances such as, monoterpenes, sesquiterpenes and their derivatives. Note that the percentage of sesquiterpene compounds $(18.7 \%)$ is higher than the amount of monoterpenes $(0.95)$.

Key Words: Apiaceae, components, GC/MS, leaves and stems, monoterpene, sesquiterpene

\section{INTRODUCTION}

Zosima Hoffm. genus (Apiaceae Lindl.) is represented in the wild flora of Azerbaijan. According to the literature, 10 species of this genus are found in the flora of the Arabian Peninsula and Asia Minor [Askerova et al., 1955; Askerov, 2006]. One species - Zosima absinthifolia Link. is spread in the Caucasus and Azerbaijan. In Azerbaijan, Z. absinthifolia is distributed in the central and southern part of the Lesser Caucasus, the Caspian lowlands, Absheron, Gobustan, Kur-Araz lowlands, Bozgir plateau, as well as in the mountainous part of Nakhchivan and Lankaran. [Askerova, 1955;
Grossheim, 1967; Ibadullayeva, 2004; Askerov, 2006]. Type is in Paris [Grossheim, 1967]. The genus is a perennial herb up to $50 \mathrm{~cm}$ tall. It blooms in April-May and bears fruit in June-July. As a hemicryptophyte and xerophyte, it grows singly or sparsely in various grassy meadows in Azerbaijan from the lowlands to the middle mountain ranges.

Z. absinthifolia had been known as a medicinal plant since ancient times in Iran, Turkey and Pakistan, the fruits of plant are used in Turkish folk medicine in diseases of the digestive system and the mixture made from the leaves in the treatment of diabetes [Ozturk et al., 2018; Sarikaya et al., 2010; Arıtuluk, Ezer, 2012]. The extract made from the seeds of the plant has a certain therapeutic value in Pakistan folk medicine for coughs and other sore throats in children [Pashtana et al., 2016], and the aerial part for the treatment of inflammation of the gastrointestinal tract and respiratory tract [Goodman, Ghafoor, 1992; Haq et al., 2018].

A number of studies have shown that octanol, $\gamma$-terpinene, octyl acetate, (-) - $\beta$-bourbonen, $\beta$-copaene, $\alpha$-cadinene, germacrene $\mathrm{D}$, spathulenol, caryophyllene oxide, nerolidol and some other compounds have been found in essential oil [Mollaei et al., 2020; Baser et al., 2018; Javidnia et al., 2008; Razavi 2013]. As a result of research conducted in Iran, the main components of essential oil were germacrene D $(20.7 \%)$, caryophylene $(14.6 \%)$ and octyl acetate (12.2\%) [Esmaeili et al., 2010].

The component composition of the essential oil of $Z$. radians, another species of the genus Zosima, was studied and the major components were citronelyl acetate $(16.3 \%)$, octyl butyrate $(15.0 \%), 3$-octenyl acetate $(12.8 \%)$, geranyl butyrate $(11.0 \%)$ and octyl acetate $(9.1 \%)$ [Kazemizadeha et al., 2011]. Quantitative and qualitative changes of essential oil in different phenological stages of $Z$. absinthifolia seeds were studied by different authors. $\alpha$-pinene, n-octanol, germacrene-D, $\beta$-caryophyllene, octyl acetate, caryophyllene oxide were the main components of the essential oil at different stages of growth [Amiri, 2008]. In different years, essential oils in seeds of Z. absinthifolia was

1'E-mail: elixanovanermin@yahoo.com

Received 22.10.2021; Received in revised form 03.11.2021; Accepted 15.11.2021 
1.89 - 2.01\% [Ibadullaeva, 2001; Ibadullaeva, 2003]. Antimicrobial properties of the essential oils of the species Z. absinthifolia were studied as well as it was certained that essential oils can be used as antifungal means [Zulfuqarova, Qasimov, 2016]. The studied species is of high importance in terms of medicine. The content of $Z$. absinthifolia includes coumarins such as zozimin, deltoin, bergapten,imperatorin, izobergapten, izopimpinellin, pimpinellin, sfondin, umbelliferon etc. [Ibadullaeva, 2003].

As a result of the analysis of literature data it was found that there were differences in the quantity and quality of essential oils depending on the environmental and geographical factors. Therefore, the purpose of the research is to study the component composition of the essential oil obtained from the leaves and stems of the species Z. absintifolia, which is widespread in Azerbaijan.

\section{MATERIAL AND METHODS}

Plant material. To study the chemical composition of the essential oil, the aerial parts (stem and leaves) of Z. absinthifolia were collected from Shahbuz region of the Nakhchivan Autonomous Republic during the flowering period.

Obtaining essential oil. The essential oil was extracted from the air-dried and finely chopped aerial parts (96 g) of the plant by the method of hydro-distillation for 7 hours [Ginzberg, 1932]. The oil yield was $0.7 \pm 0.15 \%$. Gas Chromato/Mass Spectroscopy method (GS/ $M S)$. The chemical composition of essential oil of $Z$. absinthifolia was analyzed by GS/MS method, which was carried out using an Agilent 5977A MS gas chromatography combined with an Agilent 7890 GC inert Mass Selective Detector. The column size was $30.0 \mathrm{~m} \times 250 \mu \mathrm{m}$, film thickness- $0.25 \mu \mathrm{m}$ from HP-5 MS Ultra Inert: oven temperature was $50^{\circ} \mathrm{C}$ for $3 \mathrm{~min}$., then the temperature rises by $3^{\circ} \mathrm{C}$ for each minute and reaches $250^{\circ} \mathrm{C}$ and is maintained for 5 minutes. Helium was used as a carrier gas. The compounds of the oil were determined by comparison of the mass spectral data using the Nist electronic libraries. The percentage of the components was calculated from the GC peak areas, using the normalization method.

\section{RESULTS AND DISCUSSION}

As a result of the research, it was determined that the yield of essential oil from the stem and leaves of Z. absinthifolia was $0.7 \pm 0.15 \%$. Essential oil is light yellow, fragrant clear liquid. 50 substances were identified in the essential oil, which is $97.88 \%$ of the total essential oil. The results of chromatographic analysis of the obtained essential oil are indicated in Table.

The major components of the essential oil obtained from the stem and leaves were octyl acetate $-44.76 \%$, cyclopropane, pentyl $-13.88 \%$, butanoic acid octyl ester $-9.47 \%$. The content of other components was less than $5.5 \%$. The composition of the essential oil of the studied Z. absinthifolia is dominated by terpene substances - monoterpenes, sesquiterpenes and their derivatives. Terpenes make up $19.65 \%$ of the total content of the essential oil components. Among them, the percentage of sesquiterpenes $(18.7 \%)$ was higher than the amount of monoterpenes $(0.95 \%)$.

During the initial research, the main components of the essential oil of the fruits of Z. absinthifolia in Azerbaijan were octyl alcohol, octyl-butyrate and octyl acetate. It was found that there is $2 \%$ free capric acid [Gurvich, Gadzhiev, 1938a]. However, according to our results, only octyl alcohol and octyl acetate were found in the components of the essential oil we obtained. Although according to the literature information capric acid was found in the essential oil extracted from the fruits of the plant [Gurvich, Gadzhiev, 1938b], it has not been identified in the aerial parts.

In different parts of the world, octanol, $\gamma$-terpinene, octyl acetate, (-)- $\beta$-bourbonene, $\beta$-copaene, $\alpha$-cadinene, germacrene $\mathrm{D}$, spathulenol, caryophyllene oxide, nerolidol and some other compounds the chemical contents essential oil of Z. absinthifolia. [Mollaei et al., 2020; Baser et al., 2018; Javidnia et al., 2008; Razavi, 2013]. These are consistent with our results. As a result of research conducted in Iran, the main component of essential oil was germacrene D (20.7\%), cariophylene $(14.6 \%)$ and octyl acetate (12.2\%) [Esmaeili et al., 2010]. In Azerbaijan, the amount of germacrene D was low (4.54\%) and octyl acetate was high.

A number of studies have been conducted on the antioxidant, anti-inflammatory, antibacterial and cytotoxic activity of the main components that make up the essential oil [Nascimento et al., 2018; Maggi et al., 2014]. There are quantitative and qualitative differences in the component composition of the essential oil of Z. absinthifolia collected from different areals. These depend on the collection time of plant and environmental factors. The high content of octyl acetate in the essential oil of Z. absinthifolia and its numerous biologically active properties increase the medical and practical importance of the plant. 
Table. The chemical constituents (\%) of the essential oil of Zosima absinthifolia.

\begin{tabular}{cccccc}
\hline Compounds & $\%$ & RT $(\mathrm{min})$ & Compounds & $\%$ & RT (min) \\
\hline$\alpha$-pinene & 0.22 & 8.128 & Cedrene & 2.45 & 32.373 \\
Octanal & 1.29 & 10.901 & $\alpha$-muurolene & 0.21 & 32.550 \\
p-Menth-2-en-7-ol, trans- & 0.31 & 12.020 & trans-beta-Ionone & 0.55 & 31.968 \\
Cyclopropane, pentyl- & 13.88 & 14.036 & (E)- $\alpha$-elemene & 0.07 & 32.157 \\
3-Carene & 0.16 & 15.217 & $\delta$-Cadinene & 0.89 & 33.468 \\
$\gamma$-Terpinene & 0.06 & 18.634 & $\alpha$-amorphene & 1.3 & 33.920 \\
Cyclohexane, ethenyl- & 0.20 & 19.772 & $\gamma$-muurolene & 0.82 & 34.989 \\
Octyl acetate & 44.76 & 20.612 & Valencene & 0.11 & 35.042 \\
Propanal,2-methyl-3-phenyl- & 0.04 & 21.456 & $\gamma$-gurjunene & 0.25 & 35.538 \\
Verbenylacetate & 0.26 & 22.490 & 1,4 -Cadinadiene & 0.11 & 35.560 \\
Bornyl acetate & 0.67 & 23.547 & Alloaromadendrene & 1.3 & 35.587 \\
$\beta$-elemene & 0.26 & 25.380 & Hexanoic acid, octyl ester & 0.12 & 35.877 \\
$\gamma$-pyronene & 3.03 & 25.801 & Spathulenol & 0.71 & 36.621 \\
$\alpha$-cubebene & 0.06 & 26.348 & $\gamma$-cadinene & 0.19 & 37.924 \\
Ylangene & 0.06 & 27.241 & m-mentha-4,8-diene, (1S,3S)- $(+)-$ & 0.09 & 38.765 \\
Copaene & 0.58 & 27.426 & Isocaryophillene & 0.04 & 40.091 \\
(-)-beta.-Bourbonene & 0.72 & 27.833 & Cyclohexanone, 2-pentyl- & 0.17 & 40.317 \\
$\beta$-Cubebene & 0.24 & 28.050 & Farnesol & 0.38 & 40.905 \\
Butanoic acid, octyl ester & 9.47 & 28.213 & 2,6-Lutidine-N-oxide & 0.05 & 41.244 \\
$\beta$-ylangene & 5.32 & 29.236 & Cyclooctane & 0.15 & 42.948 \\
Butanoic acid, 2-methyl-, heptyl ester & 0.43 & 29.995 & cis-Thujopsene & 0.23 & 43.323 \\
Isoledene & 0.04 & 30.492 & $\beta$-bisabolene & 0.06 & 44.259 \\
Germacrene D & 4.54 & 31.004 & (+)-Nerolidol & 0.45 & 45.065 \\
$\beta$-Copaene & 0.27 & 31.087 & Phytol & 0.22 & 53.601 \\
Calamenene & 0.05 & 31.471 & Eicosane & 0.04 & 59.018 \\
\hline
\end{tabular}

\section{REFERENCES}

Askerova R.K., Akhundov G.F., Isaev Y.M., Karyagin I.I., Irilipko L.I., Sofieva R.M. (1955), Flora Azerbaidjana Ed. Baku: AN Azerb. SSR, 7: 540. [Аскерова Р.К., Ахундов Г.Ф., Исаев Я.М., Карягин И.И., Ирилипко Л.И., Софиева Р.М. (1955), Флора Азербайджана Под ред. Баку: АН Азербайджан. ССР, с. 540]

Askerov A.M. (2006) Higher plants of Azerbaijan. Abstract of the flora of Azerbaijan. Baku: "Science", 2:188-189. [Osgərov A.M. (2006) Azərbaycanın ali bitkiləri. Azərbaycan florasının konspekti. Bakı: "Elm", 2: 197-198]

Amiri H. (2008) Quantitative and qualitative changes of essential oil of Zosimia absinthifolia (Vent.) Link. in different phenological stages. Iran J Med Aroma Plants, 24(2):217-224.

Arıtuluk Z.C., Ezer N. (2012) Plants used against diabetes among the population. Hacettepe University Faculty of Pharmacy Journal (Turkey), 32(2):1 79-208. [Arituluk Z.C., Ezer N. (2012) Halk arasında diyabete karşı kullanılan bitkiler. Hacettepe Üniversitesi Eczacılık Fakültesi Dergisi (Türkiye), 32(2): 179-208]

Baser K., Aburwais O., Demirci B. (2018) Essential oil composition of Zosima absinthifolia (Vent.) Link. from Northern Cyprus, Natural Volatiles \& Essential
Oils, 5(2): 19-23.

Esmaeili A., Amiri H., Rustaiyan A., Masoudi S., Tabatabaei M. (2010) The essential oils of two umbelliferae, Zosimia absinthifolia (Vent.) Link. and Smyrniopsis aucheri Boiss. growing wild in Iran. Journal of Essential Oil Bearing Plants, 13: 73-77.

Ginzberg A.C. (1932) Simplified method of determining the essential oil in ether. Chemical-pharmaceutical industry, 8-9: 326-329.

Grossheim A.A. (1967) Flora of the Caucasus, Baku, T. VII, p. 133 [Гроссгейм А.А. (1967), Флора Кавказа. Баку, Т. VII, с. 133]

Gurvich N.L., Gadzhiev I.Y. (1938a) Zozimia absinthifolia essential oil. Proceedings of the Botanical Institute. Baku: AzFAN, 3: 160-171. [Гурвич Н.Л., Гаджиев И.Ю. (1938а) Эфирное масло Zozimia absinthifolia. Tруды Ботанического Института. Баку: АзФАН, 3: 160-171]

Gurvich N.L. Gadzhiev I.Y. (1938b) Wild growing ethereal of the high-mountainous part of the Abrakunis district of Nakh. LSSR. Proceedings of BINAZFAN. Baku: AZFAN, 3: 137-165. [Гурвич Н.Л.Гаджиев И.Ю. (1938b) Дикорастущие эфирно маеличныевысоко-горной части Абракунисского района Нах. ЛССР. Труды БИНАЗФАН. Баку: АЗФАН, 3:137-165]

Goodman S.M, Ghafoor A. (1992) The ethnobotany of Southern Balochistan, Pakistan, with particular 
reference to medicinal plants. Fieldiana: Botany, 31: $1-84$.

Haq J.U., Muhammad S., Kanwal A., Muhammad G., Ishaque M., Baloch S. (2018) Evaluation, hepatoprotective effects and the determination of safty and efficacy of Zosima absinthifolia. Indo American Journal of Pharmaceutical Sciences, 5(10): 10892-10901.

Ibadullaeva S.C. (2001) Essential oil plants of the family (Apiaceae Lind1.) Umbrella in the flora of Azerbaijan. VILAR, Moscow, p. 182. [Ибадуллаева С.Д. (2001) Эфирно масличные растения сем. (Арiaceae Lindl.) Зонтичных во флоре Азербайджана. ВИЛАР, Москва, с. 182]

Ibadullaeva S.D., (2003) coumarin compounds and essential oils in plant fruits at different stages of their development. XI International Symposium "Nontraditional crop production. Eniology. Ecology and Health ". Simferopol, art. 454. [Ибадуллаева С.Д., (2003) кумариновых соединений и эфирныхмасел в плодах растенийна разных фазахих развития. XI Международный симпозиум «Нетрадиционное растениеводство. Эниология. Экология и здоровье». 2003, Симферополь, с. 454]

Ibadullayeva S. (2004) Apiaceae of the Azerbaijan flora, Baku: Elm, p. 374. [İbadullayeva S.C. (2004) Azərbaycan florasının Kərəvüzkimilər. Bakı: Elm, s. 374]

Javidnia K., Miri R., Soltani M., Khosravi A.R. (2008) Constituents of the oil of Zosimia absinthifolia (Vent.) Link. from Iran. Journal of Essential Oil Research, 20(2): 114-116.

Kazemizadeha Z., Yousefzadi M., Sonboli A. (2011) Volatile constituents of Zosimia radians Boiss. and Hohen from Iran. Natural Product Research, 25(10), 1004-1007.

Maggi F., Quaasinti L., Bramucci M., Giulio L., Petrelli D., Vitali L.A., Papa F., Vittori S. (2014) Composition and bilogical activities of hogweed [Heracleum sphondylium L. subsp. ternatum (Velen.) Brummitt] essential oil and its main components octylasetate andoctyl butyrate. Natural Product Research, 28(17): 1354-1363.

Mollaei S., Hazrati S., Lotfizadeh V., Dastan D., Asgharian P. (2020) Phytochemical variation and biological activities of Zosima absinthifolia during various stages of growth. International Journal of Food Properties, 1556-1567.

Nascimento K.F., Martinez F., Moreira F., Santos J.A., Aparecida C., Kassuya L., Hnerique J., Croda R.,
Amdrea C., Cardoso L., Vieira M.C., Foglio M.A., Carvalho J.E., Formagio A.S. (2018) Antioxidant, anti-inflammatory, antiproliferative and antimycobacterial activities of the essential oil of Psidium guineense Sw. and spathulenol. J. Ethnopharmacol, 10(210): 351-358.

Ozturk M., Altay V., Altundağ E., Ibadullayeva S. J., Aslanipour B., Gönenç T.M. (2018) Herbals in Iğdır (Turkey), Nakhchivan (Azerbaijan), and Tabriz (Iran) Plant and Human Health, 1: 197-266.

Pashtana S.J, Sadia B., Yousaf A., Naz N., Rehmat N., Tahira B., Sajjad N., Hameed S. and Bazai Z.A. (2016) Ethnobotanical study of flora of Gulistan, district Killa Abdullah, Balochistan, Pakistan. Pure and Applied Biology, 5(2): 361-368.

Razavi S.M. (2013) Phytochemicals from the fruits of Zosima absinthifolia, an edible and medicinal plant. Journal of Ege University Faculty of Agriculture, 2: 513-517.

Sarikaya S., Öner H., Harput Ü.Ş. (2010) Medicinal plants used for the treatment of diabetes in Turkey. J. Fac. Pharm, 39(4): 317-342.

Zulfugarova P.V., H.Z.Gasimov (2016) Antimicrobial features of essential oils of some species in Apiaceae family, SEAB2-Symposium on EuroAsian Biodiversity-Antalya-Turkey: p. 234.

\section{Zosima absinthifolia Link. növünün yerüstü hissəsindən alınmış efir yağının komponent torkibi}

\section{Normin S. Olixanova \\ Eldar N. Novruzov \\ Sevil A. Zeynalova}

AMEA Botanika Institutu, Badamdar şossesi 40, Bakı, AZ1004, Azarbaycan

Məqalədə Naxçıvan Muxtar Respublikasının Şahbuz rayonu yaxınlığında toplanmış Zosima absinthifolia Link. (Apiaceae) növünün efir yağının komponent tərkibi verilmişdir. Zosima Hoffm. cinsi Azərbaycanda bir növlə təmsil olunur. Tədqiqat üçün bitki xammalı çiçəkləmə fazasında yığılmışdır. Efir yağı bitkinin havada qurudulmuş və xırda-xırda doğranmış yarpaq və gövdələrindən hidrodistilliasiya metodu ilə alınmışdır. Efir yağının çıxımı $0.7 \pm 0.15 \%$ təşkil edir. Alınmış efir yağının komponent tərkibi Qaz Xromato/ Mass Spektrometriya metodu ilə müəyyən edilmişdir. Ümumilikdə xromatoqrafik analiz zamanı efir yağının 97.88\%-ni təşkil edən 50 maddə identifikasiya olunmuşdur. Efir yağının əsas komponentləri oktil asetat (44.76\%), tsiklopropan, pentil-(13.88\%), 
butanoik turşusunun oktil efiri $(9.47 \%)$ olmuşdur. Digər komponentlərin miqdarı isə 5.5\%-dən azdır. Zosima absinthifolia yarpaq və gövdələrinin efir yağının tərkibində həmçinin terpen təbiətli maddələr monoterpenlər, seskviterpenlər və onların törəmələri də aşkar edilmişdir. Qeyd edək ki, seskviterpenlərin faizlə miqdarı (18.7\%) monoterpenlərin miqdarından (0.95\%) çoxdur.

Açar sözlor: Apiaceae, komponentlor, QX/MS, yarpaq va gövdalar, monoterpenlar, seskviterpenlar

Компонентный состав эфирного масла полученного из надземные части из Zosima absinthifolia (Vent.) Link.

\section{Нармин С. Алиханова}

Эльдар Н. Новрузов

Севиль А. Зейналова

Институт Ботаники НАН Азербайджана, Бадамдарское шоссе 40, Баку, AZ1004, Азербайджан

В статье приводится компонентный состав эфирного масла Zosima absinthifolia Link. (Apiaceae), собранный в окрестностях Шахбузского района
Нахчыванской Автономной Республики. Во флоре Азербайджана род Zosima Hoffm. представлен одним видом. Растительное сырье для исследований собрано в фазе цветения. Эфирное масло получено методом гидродистилляции из мелко измельченных сухих и листьев и стеблей растений. Выход эфирного масла составил $0.7 \pm 0.15 \%$. Компонентный состав полученного эфирного масла определен методом газовой хроматографии и хромато массспектрометрии. В результате хроматографического анализа эфирного масла было идентифицировано 50 веществ, на долю которых приходилось $97.88 \%$. Ведущие компоненты эфирного масла были октилацетат (44.76\%), циклопропан, пентил- (13.88\%) и октиловый эфир бутановой кислоты $(9.47 \%)$. Содержание остальных компонентов составило менее $5.5 \%$. Эфирное масло из листьев и стеблей Zosima absinthifolia содержит также терпеновые вещества - моно-, сесквитерпены и их производные. Установлено, что процент сесквитерпенов (18.7\%) превышает количество монотерпенов $(0.95 \%)$.

Ключевые слова: Apiaceаe, компоненты, ГХ/ХМС, листья и стебли, монотерпены, сесквитерпены 